\title{
Re-examining the History of the Great Famine in China through Documentary Evidence
}

\author{
Zhou Xun \\ University of Essex
}

\begin{abstract}
This paper examines documentary evidence that has emerged from the Chinese state archives showing that from the outset, the Great Leap Forward failed as a method for improving agricultural productivity; that its failure was quickly evident and purposefully ignored; and that the level of human suffering and death was greater than has been suggested. In addition, in contrast to the image of a strictly disciplined communist society in which errors at the top cause the entire machinery to grind to a halt, the portrait that emerges from archival documents is one of a society in deliquescence, as people resort to every means available to get by as well as they can.
\end{abstract}

Keywords: Famine, Communism, China, Terror, Archive, Cannibalism

\section{INTRODUCTION}

$\mathrm{T}$ he Great Famine ${ }^{1}$ of 1958-62 in China, which claimed tens of millions of lives, is the worst famine in human history. It was the direct result of the Great Leap Forward (hereafter GLF)-Mao Zedong's campaign to industrialize China and lead the country toward a communist utopia.

Before the Communist victory in 1949, private land ownership was the basis of agriculture in China. The growing population contributed to an escalating land shortage problem. The lack of land and private land ownership subsequently became directly linked to poverty. In the early 1940s Mao, the new supreme leader of the Chinese Communist Party (CCP), declared that agricultural collectivization was the only way to eliminate rural poverty. The socialist system of agriculture was supposed to vastly improve land productivity, stimulate rural markets for industrial products,

1 Great Famine is a term used for a number of large-scale occurrences of extreme food scarcity throughout history, including in Medieval Europe, Ireland, Ukraine, and China. In the case of Ukraine, the name Holodomor has come to displace Great Famine since it was brought into use in the late $20^{\text {th }}$ century. 
and redirect sufficient numbers of workers and funds toward accelerating industrialization (Mao 1967, 153-61). A similar program carried out in the Soviet Union under Stalin ten years earlier had led to widespread resistance and a devastating famine in Ukraine (Conquest). Nevertheless, Mao pushed for collectivization in the Chinese countryside.

As soon as the CCP consolidated its power in the early 1950s, it began enforcing rural collectivization, a policy that Mao and the CCP leadership saw as integral to building a new socialist consciousness among China's masses in the countryside. In the winter of 1952, the Mutual Aid Group (互 助组) was implemented throughout rural China; later, this structure was replaced by agricultural collectives. But Mao was not content with the speed of the initial stage of collectivization. He wanted a fully socialist agricultural system established throughout the country, and he wanted it fast. In 1955 he pushed through the leftist economic policies of the Socialist High Tide（社会主义高潮）to speed up the process of incorporating individual peasant families into agricultural cooperatives. Once it was launched, the collectivization campaign swept through China. For a variety of reasons, including easing administrative burdens and building up local power bases, a huge number of provincial and local cadres embraced the campaign enthusiastically. This phase became known as the Little Leap Forward (小冒进).

The pace of the collectivization was astonishing, and it proceeded even faster than Mao had expected. By 1956 virtually all agricultural households in rural China had been organized into farming collectives. While this early stage of the collectivization did not provoke widespread resistance and suppression, as it did in the Soviet Union, dissatisfaction and unrest were indeed widespread (Zhou 2012, 142-47; High 81-107). Faced with warning signs, Mao showed no hesitation. He wanted an even greater leap forward to ensure the Communist writ reigned in all aspects of life in the countryside. He subsequently revived the slogan "More, Better, Faster, and More Economically," which became the rallying cry in the campaign for China's rapid modernization.

Mao's push to go farther was also a response to the setback of his leftist economic policy. In the latter half of 1956, a number of top CCP leaders, including Premier Zhou Enlai, were concerned that collectivization was progressing too rapidly. Their concerns about the "blind advance" (急躁冒 进) and calls for a slowdown displeased Mao. Elsewhere that year, in February, the new Soviet leader Nikita Khrushchev delivered his secret speech marking the beginning of de-Stalinization, which brought many Eastern European countries hope for freedom and change; and in October the short-lived Hungarian Revolution broke out. A month later, on 4 
November, Soviet forces violently crushed that revolution and Budapest was awash with blood. In China unrest also spread, echoing the events in Eastern Europe. Mao was obliged to drop his Socialist High Tide program, to delete from the Chinese constitution references to the political theory known as "Mao Zedong Thought," and to denounce the cult of his personality.

However, internal unrest and external events provided Chairman Mao an opportunity to reclaim his earlier initiatives. He started by launching the rectification campaign in the CCP to "extirpate the demons and bastards." In February 1957 in his most famous speech, "On the Correct Handling of Contradictions among the People," Mao once again emphasized the need to "let a hundred flowers bloom and let a hundred schools compete." By allowing "hundreds of flowers to bloom," Mao successfully rallied most Chinese people around him, in particular the intellectuals. More than 12 million CCP members and 5 million non-partisan intellectuals took part in the campaign to help correct the Party's mistakes. But in the summer of 1957 Mao unexpectedly launched the Anti-Rightist and rural Socialist Education Campaigns, and put Deng Xiaoping in charge of both. The primary targets of the Anti-Rightist Campaign were the so-called "bourgeois rightists" - non-partisan persons who had responded to Mao's call to criticize the CCP on all manner of topics, but who, Mao decided, had gone too far. More than half a million people were labeled "bourgeois rightists" and were soon disposed of (Ebrey 458).

Mao was then able to seize the initiative to relaunch the idea of a leap, and "Mao Zedong Thought" was reinstated, becoming the leading banner for the CCP and the entire country. In January 1958, at a meeting of top CCP leaders at Nanning, Mao pressured Premier Zhou Enlai into public selfcriticism for his part in encouraging "right-deviationist conservative thinking" in trying to persuade Mao to halt the earlier version of the GLF. A few other leaders were also criticized for the same reason (Bo), and any voices opposing collectivization were silenced. Until this point, it seemed that all of the top leaders were working together (Li).

A few months earlier, in November 1957, Communist leaders from around the world gathered in Moscow for the first major Communist conference since Stalin's death. There Mao decided to take on the challenge of being the new leader of the Communist world. After Khrushchev announced that the Soviet Union would overtake the United States in economic production, Mao declared that China would overtake Britain in steel output within fifteen years. Meanwhile a massive water-conservation campaign was launched in China; it marked the beginning of the GLF. Soon after, in the spring of 1958, the full force of the GLF was unleashed, with Mao at its helm. In August 1958, at the CCP's Politburo meeting, it was 
decided that all aspects of economic, political, and social life would be collectivized and that the people's commune would be the new and only form of organization for rural China. ${ }^{2}$ By the end of the year, according to an official estimate, nearly 99 percent of the peasants had joined a commune. Approximately 26,000 communes had been set up, each with an average of 5,000 households. With the establishment of people's communes in 1958, the CCP's goal to control all land in the countryside, as well as all wealth, was finally accomplished.

The general image of the year 1958, projected then and later, is that the entire country was united in rapturous enthusiasm for the GLF, and that by the end of the year steel, coal, and industrial output had been massively boosted and the production of grain and cotton had increased considerably. It looked as though Mao's communist dream was on the verge of becoming a reality in the countryside and that the fifteen-year plan would be achieved in five years. But the reality was very different. For most of China's rural population, the GLF was an unmitigated disaster. The CCP collectivized everything: villagers lost their homes, their land, their livelihoods, and their personal belongings, from pots and pans to grandma's needles and the baby's diapers. "Other than your teeth, nothing belongs to you," a member of the village cadre in Anhui province's Fengyang county announced publicly. In Fengyang villagers were driven out of their homes to live communally. Normal family life was destroyed because families were divided up to work on different agricultural projects at different locations (Wang 165, 178-81). To achieve the government's cotton collection quotas, villagers even had their quilts and padded jackets confiscated that they depended on to keep warm in winter (Zhou 2014, 26).

Deprived of homes to live in, tools to work with, food to eat, and private possessions of any kind by the radical collectivization, China's peasants lacked the resources to engage in communal labour. They had little incentive, and slacking off at work was a common practice. Some villagers pretended to be sick, while others spent most of their working hours standing in the fields smoking pipes. In Hunan province it was reported that many villagers showed no sweat after supposedly working a whole day in the fields. In Guangdong province's Xinhui county, a place that produced many revolutionary intellectuals in the late $19^{\text {th }}$ and early $20^{\text {th }}$ centuries, the

2 See Mao Zedong's speech at the Beidaihe Conference, 19 and 21 August 1958 (Zhou 2014, 13). 
local cadres had become disillusioned and lost confidence in reaching the goal of the GLF because most villagers regularly found excuses not to work. ${ }^{3}$

In addition, because the entire rural population had been mobilized to carry out irrigation projects and the mass production of iron and steel, no one was left in the countryside to plant rice or cultivate the half-grown crops, which were therefore left to rot in the fields. Agricultural land turned into wasteland, and livestock was left unattended and died. To meet the ever-inflated government procurement figures, local CCP cadres and villagers had little choice but to dissemble.

Gigantic dams were built throughout the country to generate more power, resulting in millions of rural residents being uprooted from their homes (Jun 71-73). Most of these crude projects turned out to be an enormous waste of time and resources, and the ecological consequences continue to affect people's lives and the environment to this today.

Scholars still debate the number of famine-related deaths. Yang Jisheng has estimated that during the four years of the famine at least 36 million people died. Frank Dikötter has suggested that at least 45 million people were killed in this, the worst famine in history. Other historians in China have put the death toll at 55 million, almost the same as the total number of deaths in the Second World War (Yu).

Yet, unlike the Holocaust, the Holodomor, or other major human catastrophes in the 20th century, there is no place in China's collective memory for the Great Famine. In fact, the history of the Great Famine has long been obscured by official taboos and restricted access to primary sources. Until recently very little archival material on the subject was available to historians or the general public. Therefore the Great Famine has remained very much hidden and forgotten-a blank spot in Chinese history. There is no mention of it in any history textbook in China, and it has been left out of the official Communist historiography. The accepted term in China for this period is "The Three Difficult Years" or "Three Years of Natural Disaster."

\section{THE ARCHIVE}

After the CCP drove out Chiang Kai-shek and his Nationalist government in 1949, it inherited a vast amount of archival documents from previous regimes, including those from the Ming and Manchu periods as well as

${ }^{3}$ Neibu Cankao, 19 January 1959; and Mao 2008, 19-21. 
those from the Republican period. In November 1954, China's National Archives Agency was established (also known as the State Archives Administration). For a while it was administered by the State Council. On the local level, each province and county also established archives responsible for safeguarding local documents, including those from the imperial and republican periods. These local archives have been under the administration of the National Archives Agency. Besides gaining control of the archives of previous regimes, the CCP quickly established that archiving of Party documents was an integral part of the CCP's attempts to consolidate its newly gained power. In 1959 its Central Committee (CC) decided that the State Archives Administration of China should be a CCP organ directly administered by the CC. In the meantime, the Central Archive was established in Beijing (it was later merged with the State Archives Administration to become one organization). The latter, as well as provincial and county archives, has been the repository of official CCP records. Since these records belong to the CCP, no individual is allowed access to them. To this day, many provincial and county archives are housed inside local CCP premises and guarded by armed soldiers.

In the early 1990s the State Archives Administration was substantially transformed as part of the CCP's drive for decentralization. In the middle of this change, new archival regulations were published in November 1990, and subsequently revised in May 1999. These regulations theoretically made documents over thirty years old available to historians and the general public. In practice, however, this has not always been the case. A great number of documents, including those on the famine, are still classified as "unsuitable" for public access, and they continue to be deemed "closed" or "sensitive" files. Even those files classified as "open" are not always accessible.

This author is one of an increasing number of historians who are pioneering a new history of the People's Republic of China through the use of oral and archival evidence. I began researching the Great Famine in 2006, and during the next five years I travelled across rural and urban China-to Sichuan, Hunan, Henan, Anhui, Shandong, Yunnan, Guizhou, Guangdong, Guangxi provinces and many other places-to interview famine survivors and read hundreds of CCP records in archives throughout China. Through perseverance I have managed to access archives that no one has seen, at least to my knowledge, including leading historians in China. By painstakingly working in small and large archives, I have pieced together hundreds of fragmented documents and thus created a fuller picture of the famine. My book The Great Famine in China, 1958-1962 and its companion volume, The Forgotten Voices of Mao's Great Famine, are the fruits of my research during those five years. 
During that time I experienced a number of ups and downs in the archives. When I first started my research in 2006, I was able to read a huge number of documents. By December 2007, however, many of the files I had been able to access before were removed from the open catalogue. There was no explanation. To overcome this obstacle, I adopted the strategy of moving from one archive to another and hoping for the best. To some extent this worked, because accessibility varied in every archive, province, and county. It is curious that in a one-party state like China such variation exists. Not only does each archive have its own rules, but the degree of accessibility granted is, to an extent, at the discretion of the archive's staff. In my own experience, sometimes even though I had a letter of approval or a rubber-stamped pass, I was only allowed to see limited types of material. On a number of occasions, an archive staff member thoroughly examined every file I requested before allowing me to read it. The worst experience I had was in Sichuan province's Ya'an region, where almost half of the population had perished in the Great Famine. I visited a number of county archives there, but on three occasions archival staff refused to let me read the files I had ordered because the terms "death by starvation" and "revolt" appeared in the titles. The staff at the Henan Provincial Archive did not even allow me to consult the catalogue and suggested that I consider changing my research focus to a period before 1949.

Although in the Chinese archives famine is still a proscribed subject, a fair amount of the open documents sheds crucial light on the period. One term I found useful was grain procurement (统购统销). Younger employees of archives often had no idea what it meant, so they rarely raised objections when I requested documents on that subject. On a number of occasions they simply told me to take a look at the catalogue myself: "If it's in the catalogue, you can request it."

Unfortunately, this openness changed after the leadership transition that took place in the autumn of 2012. Three months before the XVIII National Congress of the CCP in August 2012, the State Archives Administration issued an edict banning historians from reading archival documents from the year 1949 onwards because "they are likely to publish their research." As result, a huge number of the documents that I managed to get and publish in The Great Famine in China are no longer available to researchers. All the documents in the provincial Party Committee files have been withdrawn, and in most provinces one is not even allowed to see catalogues unless one obtains permission from the Party Committee. Because most of the documents I included in The Great Famine in China have become inaccessible, my volume is currently the only historical record of what happened at the time. 
More than 100 documents that are included in The Great Famine in China have already helped to transform our understanding of what really happened on the ground during the period of the GLF and the Great Famine. These documents cover everything from collectivization and survival strategies to causes of death. They include reports and instructions of the CCP's CC, its Secretariat, and provincial CCP committees; letters from individuals; official speeches and conference minutes; and public security investigations into robberies, thefts, murders, and cannibalism. All of these documents are from CCP archives in various provincial, city, and county facilities. Most of them were written by the government's investigating agents or Communist cadres for a particular purpose. Quite often the intention was to expose corruption at the local level. It was understood that although numerous local officials were responsible for extreme violence, forced starvation, and countless killings in the countryside, Mao's utopian project was completely blameless. Terms such as "sabotage" and "counterrevolutionary" were often employed to obscure what was really happening in remote villages. Despite their original intended audience and the CCP's terminology, the details, descriptions, and data that these documents provide are invaluable for understanding the past. They allow today's readers to gain insight into the relationship between the state and the peasantry.

As mentioned earlier, the official image of the year 1958 has been that the entire country was united in rapturous enthusiasm for the GLF, which produced a bumper harvest in the countryside. Yet a 25 April 1958 telephone report from the CC's General Office that I found in the Hunan Provincial Archive shows that there were already severe food shortages, starvation, and disturbances in 16 provinces and autonomous regions throughout the country. In Anhui, for example, some 1.3 million people were "without food supplies." In Shandong it was reported that 670,000 people "have had their food supplies completely cut off, and more than 150,000 have fled their home villages." Even in Guangdong, one of the wealthier provinces, there was a serious famine in the spring. As a result, almost a million people suffered starvation (Zhou 2012, 10-16). Another document from the Shandong Provincial Archive-namely, a 29 January 1959 report by the Jinan Municipal Investigation Team-shows that there was a devastating famine in the region near Jinan. After they consumed everything edible, the villagers were reduced to selling their possessions, including their children, to stay alive (Zhou 2012, 4-10).

In general, we tend to associate famine with a lack of food and the resultant misery and death from starvation. What makes the Great Famine 
different from the famines in late imperial China and the Republican period is the extraordinary level of violence meted out in the people's communes. I was shocked by the evidence my archival research revealed. Most of the documents I uncovered show that terror and violence were the very foundation of the GLF. Mao conceived of the people's communes as environments without legal safeguards and as organizations operating strictly along military lines (Mao 2008, 573). Organized violence was practiced as an effective means of control. The aim was to "kill one in order to deter one hundred," or, as a Chinese proverb says, "Kill the chicken to scare the monkey." In many parts of the country, violence and repression were practiced with impunity. Local cadres regularly used their positions of power to extract benefits for themselves and punish those whom they disliked or with whom they disagreed. The regime encouraged what were known as "struggle sessions," during which people were punished as a warning to others in front of crowds and forced to confess to crimes; these "sessions" also provided opportunities for personal revenge. An enormous number of people were tortured because they happened to have been born into the "wrong class." On occasion family members were even forced to torture one another.

As famine took hold in China in the spring of 1959, grain production failed. The procurement systems for the acquisition of grain and other agricultural products broke down in large sections of the country. In order to meet the government's unrealistically high quotas, many local cadres used violence to dragoon the work force. People were constantly tortured to work harder. The "people's commune" was worse than the Soviet Gulag in many ways. The methods of torture were brutal. In Sichuan province's Wanxian region, for example, the methods of torturing villagers included hanging, prolonged beating, forcing them to kneel on burning charcoal, piercing their mouths, clipping off their fingers and stitching their lips, pushing needles into their nipples, force-feeding them with feces, stuffing dried beans down their throats, and so on. Parents were made to beat their children, and children to beat their parents. Many were beaten to death, and some were buried alive. To destroy the evidence, local cadres burned all the dead bodies (Zhou 2012, 21-22). Dikötter (xi) has estimated that at least 3 million people were tortured to death or killed deliberately in China between 1958 and 1962.

Along with torture, humiliation was also widely practiced. In imperial China, public humiliation was used as a form of punishment. Under Mao's leadership, humiliation was an essential tool for carrying out political violence. During the GLF period, villagers in many people's communes were regularly forced to wear tall hats and shamed in front of the local populace; some also had their faces tattooed. The cadres tried every possible means to 
break down the peasants emotionally and physically, and many villagers committed suicide as a result. In Guangdong province, for example, a 1959 report of the Procuratorial CCP Committee shows that personal humiliation was widely promoted in many counties. "In Zhan county's Nada commune, two women stole to survive. Local cadres, together with several militiamen, tied them to a tree, stripped off their clothes, and focused torchlights directly on their genitals. One of the cadres also painted two big turtles on their backs and forced the two women to display them for three days. In the end both women committed suicide" (Zhou 2012, 30-31). In Hunan province, some female villagers were forced to work naked in the freezing winter cold. The logic was: they would work harder in order to keep warm. While the cadres watched these women with pleasure, the victims cried out, "Since the day we came out of our mothers' wombs, we have never felt so humiliated" (Zhou 2012, 39-42).

In addition, the peasants were subjected to widespread looting of their houses, open theft, food deprivation, and heavy fines. Many villagers lost not only their possessions but also their children, and wives were forced to leave their husbands. A 29 December 1960 report to the Guangdong Provincial CCP Committee states that "looting of private houses has become a poisonous wind sweeping across [Encheng] Commune in [the Jiangmen region]," and "86.2 percent of villages and 83.1 percent of individual peasants' houses ha[d] been looted" in that commune. On the eve of radical collectivization, villagers lost their land, houses, oxen, agricultural tools, pigs, poultry, grain, and seeds. At the end of 1958, during the Anti-Hiding Campaign, more than 200 incidents of looting took place. The most severe looting took place then when the local CCP secretary used that campaign as an excuse to form a looting squad. Under his command,

The looters surrounded four villages within the brigade and arrested a number of local cadres. Some cadres were detained for more than five days. The looters also imposed curfews forbidding people to go out. If any person broke this curfew, the militia would shoot him or her with impunity. The looting went on for 11 days, and the looters spared neither the interiors nor the grounds of people's houses, or even the woods on the hill. They not only excavated people's land and dug under their walls, but even dug beneath their beds; they also rummaged through boxes and cupboards. In the end they confiscated $230 \mathrm{~kg}$ of rice, $424 \mathrm{~kg}$ of fennel, $4 \mathrm{~kg}$ of rice flour, $10 \mathrm{~kg}$ of seeds, $83 \mathrm{~kg}$ of grain, $85.5 \mathrm{~kg}$ of sorghum and wheat, $144 \mathrm{~kg}$ of beans, and $268.5 \mathrm{~kg}$ of rice cakes, as well as 10 plows and some beef fat, salt, sugar, and poultry. The poultry, fat, and sugar were taken to Shadi big brigade and were feasted on by those who took part in the looting. (Zhou 2012, 26-27)

The same document also reported that: 
471 peasants have been deprived of food.... In 1959 a poor peasant named Lu Maonu, from Huancheng big brigade, stole some rice while she was working in the collective canteen. When she was found out, the local cadres searched her home and confiscated $9 \mathrm{~kg}$ of grain rations [intended] for her entire family. They also punished her with two days of hard labor. For five days, they even refused to serve any food to her father-in-law and motherin-law. Lu, while desperately hungry herself, felt worse watching her husband and family being punished. She told her husband, "I must accept responsibility for my own sin," and committed suicide. After hearing about Lu's death, however, the local CCP secretary did not make any effort to help solve the problem. Instead, he said, "Once it's dead, it's over.... Ten dead bodies make five pairs; using them to make fertilizer will guarantee a high yield." (Zhou 2012, 27)

A huge number of archival documents I uncovered also show that the CCP leadership in Beijing knew well the extent of starvation and suffering, but they ignored the problems and carried on with the GLF nevertheless, believing that death was necessary in order to reach their utopian goal. Early on in my research I came across a striking document in the Hunan Provincial Archive on the Luliang Incident in Yunnan province. Under Xie Fuzhi's leadership, in January 1958 the Yunnan Provincial Government engaged 90 percent of the local population in the GLF's water conservation projects. The goal was to fully irrigate more than 10 million hectares of land in Yunnan within one year. Villagers were forced to work for more than 10 hours a day, sometimes all night long, with very little to eat. In February, widespread edema was reported at Luliang county's Xichong Reservoir construction site, and a large number of people died. The local cadre who reported the incident was denounced for undermining the GLF. After that no one dared reveal the truth.

The situation quickly worsened. A major famine broke out, and the death toll rose sharply. Soon edema and death became widespread in a number of neighboring counties, but anyone who dared to report the problem was purged as a "rightist." By 15 August, at the height of the GLF, some 169,000 cases of edema had been reported in Luliang county and in nearby counties in the Qujing region, and nearly 24,000 people had died. Many families fled the famine. In September the Qujing Regional Government documented the Luliang Incident, and the Yunnan Provincial CCP Committee sent the report to the CCP's CC with an additional note of self-criticism, blaming the catastrophe on the corruption of local cadres who had no "concern for the people" and were not "politically driven." Upon reading the report, Mao merely replied, "This is a good report. The Yunnan provincial government made a mistake, but they have realized that there was a problem, and they have dealt with the problem correctly. They have learned their lesson, and they will not make the same mistake again. This is 
a good thing: turning disaster into a blessing" (Zhou 2012, 173, 183). ${ }^{4}$ Echoing Chairman Mao, the central leadership in Beijing dealt with the matter by issuing an order that everyone in the country consume at least 2,500 calories a day. Both Mao and the government ignored the crucial fact that there was an endemic famine in the country and that a large number of people were dying in the course of the GLF. Instead of examining the central policy, they simply blamed local corruption. Not long after the Luliang Incident, Xie Fuzhi, Yunnan province's CCP secretary, who was responsible for launching the irrigation projects that had led to massive starvation and death, was promoted to China's minister of public security.

Around the same time, as huge numbers of people were dying in the Qujing region, on 21 August 1958 Mao addressed the sector panel of an enlarged Politburo meeting. He spoke of reviving military traditions: "Many people died for the revolution. Revolution is priceless. Why can't we do the same today?" Mao stated that sacrifice was necessary in order to accomplish the GLF, even if this meant the loss of life..$^{5}$ Human life was cheap, and Mao's view was widely shared within the CCP leadership. For example, when meeting with a Polish delegation, Chen Yi, China's foreign minister and deputy prime minister, argued that death was the price one must be prepared to pay to build socialism, and he used the enormous number of casualties during the Chinese Civil War as an example. ${ }^{6}$ Local cadres expressed similar views. In Sichuan's Wanxian region, for example, some cadres claimed, "A few dead is nothing. The amount of food is limited, it's the result of our socialist system... [which] determined that death is inevitable. In the Soviet Union, in order to build the socialist system, about 30 percent of the population died" (Zhou 2012, 22).

By the end of 1959 the famine worsened and the violence in the countryside became frenzied. Terror and starvation stripped villagers of the last remnants of their human dignity. In order to survive, some people resorted to eating the flesh of corpses. Several archival documents from the Gansu Provincial Committee in northwestern China describe such cannibalism (Zhou 2012, 62-67). The report by the Linxia branch of the Government Solicitude Group stated that in 1959 there were more than fifty cases of cannibalism in a small area in Linxia Prefecture. In each case the reason was survival. Several starving people even killed family

4 See also "A Lesson to be Learned" (November 1958), Hunan Provincial CCP Committee Archive, file 141-2-76, 98-103.

5 Hunan Provincial CCP Committee Archive, file 141-1-1036, 27.

${ }^{6}$ Hunan Provincial CCP Committee Archive, file 141-1-1051, 123 
members and consumed their flesh (Zhou 2012, 62-63). A huge amount of cannibalism was reported in eastern Sichuan and Guizhou provinces of southwestern China. One desperate female villager in eastern Sichuan strangled her five-year-old son with a towel and consumed his body in four separate meals (Zhou 2012, 69). In Guizhou's Chishui county, another female villager pleaded with her local brigade leader to give her food. He refused her entreaties, so after her six-year-old daughter died the woman ate her heart and liver (Zhou 2012, 139-40). Yet, when local police reported instances of cannibalism to the local CCP boss, he became enraged and accused them of undermining the GLF (Zhou 2012, 119).

In the archives, I regularly came across investigators' reports showing that local authorities concealed information about the famine and forged death statistics out of fear of getting into trouble or to receive more food rations. A report from the Ministry of Public Security states that in 1962 a commune in Gansu province increased the census figure by 1,252 to receive a larger cotton ration. In Henan province's Xinyang region, almost every brigade inflated its population figures, and thus more than 140,000 false persons appeared in the census report. ${ }^{7}$ In Anhui province's Taihe county more than 85,000 people died in the famine in 1960 , but the local official reported only 68,000 deaths. One district CCP secretary in that county forbade other officials from reporting the actual number of deaths, stating that the "figure is top secret. If anyone dares leak it, he must take full responsibility." As a result his district reported only a third of the total number of deaths. ${ }^{8}$

In addition to concealing the number of deaths, local authorities also prevented villagers from sending letters of complaint to higher authorities. One Public Security investigative report from in Guizhou province indicates that a local CCP secretary ordered local Public Security officials to confiscate some 100 letters of complaint to higher authorities, labelling them "anti-socialist" and "counter-revolutionary." One intercepted letter to Mao from a member of the local propaganda department reported on the mass starvation and exaggeration of output. Consequently, he became a target of "struggle" and public humiliation and was sentenced to hard labour (Zhou 2012, 148-49). In Sichuan province a villager implored "higher authorities" to "save our lives" after his brigade's CCP secretary confiscated all of the peasants' rations and they were forced to survive by

${ }^{7}$ Chishui County CCP Committee, file 1-A14-15.

8 Fuyang Region CCP Committee, file J3-2-278. 
eating grass and bark. The secretary uncovered the identity of the author, forged evidence against him, and had village bullies savagely beat him. Not long after, 128 peasants in that brigade died of hunger (Zhou 2012,149).

As the famine unfolded, a full repertoire emerged of interactions between ordinary people and state authorities in times of hunger and death, ranging from enthusiastic participation and passive conformity to supplication, manipulation, stealthy resistance, and even active opposition. A number of archival documents demonstrate that despite, or perhaps because of the suffering, there was considerable resistance to and protest about collectivization and its consequences. These everyday actions are what James C. Scott has called "weapons of the weak." Unlike in the Soviet Union, where collectivization turned into physical conflict between the state and the peasantry, in China many rural villagers used words as their weapons to express their discontent, question the socialist system, and expose corruption at the local level. In a one-party authoritarian state, where public debate or protest was not permitted and speaking out could lead to serious trouble, rumor became a tool for many peasants to voice their anger, denounce cadres, and seek redress. Many of the rumors were about death and starvation, and quite a few were apocalyptic in scope. For instance, in parts of Sichuan close to Tibet, rumors circulated about "the heavenly army coming soon, and Chairman Mao will not last long," "a march to Beijing to overthrow Chairman Mao," "restoring the emperor back to the throne, and once the emperor has been restored, all old people will become high officials and there will be food to eat and clothes to wear." There was a real sense that the famine was a heavenly sign that the mandate was to change. The Communist leadership lost the support of the peasantry, which had been the bulwark of its power in those areas (Zhou 2012,107).

Others took up the tradition of complaint by means of letters and petitions to the CCP. Beginning as early as $64 \mathrm{BC}$, subjects of the Chinese empire regularly wrote letters to the emperor to voice their grievances. This practice was formally included in the imperial law codes during the period of the Tang dynasty. After the fall of the imperial system, the new republican government regarded the right to petition as a fundamental human right, and it was clearly stated thus in the 1914 state constitution. When the Communists took power in China in 1949, from the Secretariat of the CCP and the State Council down to the grassroots level government, units were assigned the task of handling petitions and answering letters of complaint. Therefore people did not stop writing them, even while there was no formal petition system in China until February 2000. In 1950 the State Council received nearly 4,500 letters of complaint, some 700 of them addressed to Mao. 
The number of complaints increased after the launch of collectivization. In Sichuan province's Mianyang region alone, more than 10,000 letters of complaint were written each year. Similar numbers were reported in other regions of Sichuan (Zhou 2012, 146). One document from the Sichuan Provincial Archive states that in 1957 some 400 to 500 petitioners from 14 different provinces arrived each month at the Central Rural Affairs Commission in Beijing to oppose collectivization (Zhou 2012, 146-47). Another document from the Shangdong Provincial CCP Committee indicates that from 1 to 15 February 1959, 266 letters of complaint were passed down from the CC of the CCP or sent directly to the Provincial CCP Committee. All of the letters concerned food crises in the countryside (Zhou 2012, 152). Despite the attempts of local officials to suppress these letters, villagers never stopped writing them, perhaps because these letters provided them with a sense of hope and thus helped them to survive such devastation. One document in particular moved this author to tears: a 1960 memorandum from the CCP's CC stating that a poor peasant girl from Henan province wrote a letter to Mao complaining about the injustices that local cadres had committed against her father and sister. Afraid of persecution, she kept the letter stitched inside her jacket for over a year (Zhou 2012, 150).

Villagers used posters as a weapon in opposing collectivization and officials. In northern Sichuan's Langzhong county dissatisfied villagers posted more than 100 copies of an anti-Communist bill and threatened to take over Beijing (Zhou 2012, 161). In eastern Sichuan some villagers used posters to humiliate a corrupt local official (Zhou 2012, 160). More often villagers used posters to denounce collectivization and the CCP. In Guizhou's Huishui county, a poster was put up on the wall of a collective canteen, stating, "The people's commune is great, but we have no food to eat. The collective canteen is wonderful, but we have to beg for food at each meal. The CCP cares for us, yet we are forced to perform hard labour. After one day of hard work, we get only three bowls of watery rice porridge to eat. We work day and night, but we are paid nothing. Dear friends, the days of eating rice are gone forever." Also in Guizhou, at a commune in Guancheng, Kaiyang county, a poster was found on the wall of a public toilet, stating, "What's good about the CCP? All we get is two meters of fabric and $0.2 \mathrm{~kg}$ of oil. If we want to eat any more oil, we squeeze hard and our tears run out" (Zhou 2012, 107). Farther south, a series of posters mocking the people's commune system was uncovered by the local CCP secretary. They recount life in the people's commune as follows:

1. In the people's commune everyone shares a bowl of rice porridge.

2. In the people's commune coarse grains have replaced rice. 
3. In the people's commune private housing has been replaced.

4. In the people's commune the [collective] accommodation is not rainproof.

5. In the people's commune old people and children have become soldiers.

6. In the people's commune people's clothing has become shabby.

7. In the people's commune married couples cannot bear any children.

8. In the people's commune there is no meat to buy at the market.

9. In the people's commune villagers cannot build individual housing.

10. In the people's commune there is no tobacco to smoke.

11. In the people's commune people have no hats to wear in the rain.

12. In the people's commune people have no cash in their pockets.

13. In the people's commune no one has any relatives or family left.

14. In the people's commune there is no household furniture or oil or salt to cook vegetables with.

15. In the people's commune villagers cannot keep poultry, there is no alcohol to drink and no porridge for lunch.

16. In the people's commune if someone dies, there is no coffin to bury [that person] in." (Zhou 2012, 159)

To survive the famine, people employed a whole range of strategies, from stealing or hiding food to robbing state granaries. The image that emerges from a wide range of archival documents is that of a society in deliquescence, during which people resorted to every means available to get by. It is far removed from the stereotype of obedient and devoted comrades blindly following orders. Collectivization led to a chaotic society in which theft, sabotage, banditry, and murder were rife, because everyone was pitted against everyone else. A report from the Ministry of Railways shows that between September and December 1960 there were more than 1,270 food robberies along the railroads managed by its Beijing Bureau. The amount of food lost totaled $80,415 \mathrm{~kg}$. And along the railroads managed by the Gansu Bureau, more than $41,000 \mathrm{~kg}$ of food were stolen within half a month in January 1961. Several armed robberies were also reported in other parts of the country. The ministry was alarmed by the seriousness of the situation: "If this continues, it will not only cause severe damage to the railway transport system but also affect the security and stability of the entire country" (Zhou 2012, 129).

As the famine worsened, many villagers developed or rediscovered ways to cope with hunger by eating earth, worms, decomposing animals, and human flesh on a daily basis. Some of the techniques used, or substances people ate, were recorded in the Materia Medica for Famine Relief, Collection of Wild Vegetables (Yecao bolu 野菜博录, ca 1622) and other Ming records on famine foods. Although these traditional practices temporarily relieved hunger, death as the consequence of eating poisonous 
food substitutes was common throughout the country. In Sichuan's Neijiang county, starving orphans were regularly seen rummaging around local markets and looking for wild grass, dead fish, shrimp, and toads to eat. Many became ill, and some died of food poisoning (Zhou 2012, 50). In November 1960, after failing to deliver famine relief, the central government in Beijing launched a nationwide movement to collect and manufacture food substitutes or alternative foods. The result was another disaster. Within a month, outbreaks of food poisoning had spread across the whole of China, to the alarm of the central government (Zhou 2012, 50).

Many villagers fled their villages or sold everything they had, including their children, for a bowl of grain. Women left their husbands and children to remarry and have children elsewhere. Prostitution and child marriage, which were banned under the Communists, resurfaced. In Guizhou province many desperate families sold their daughters as child brides in exchange for food (Zhou 2012, 134). In Sichuan's Neijiang county some sixty cases of marriage fraud were reported in 1962 (Zhou 2012, 135). Facing calamity, selfishness became the norm. One person's gain was always another person's loss. To secure the odd mouthful of food, desperate people were ready to steal from one another, or even to commit murder. Time and again there was violent strife over food within families, leading to broken marriages and cases of brutality.

The destruction wrought during the GLF is also evident in a huge number of documents recording the enormous damage to the environment and agriculture. To transform China into a fantasized industrial superpower required a great deal of steel. Consequently many of China's mountainous regions were deforested to provide wood for backyard furnaces, and in some areas forests were converted to rice fields or to make way for irrigation canals. This deforestation led to soil erosion and sandstorms. As archival documents show, many paddies turned into "sandy beaches," and farmland turned into bogs. In China's northwest, according to a report to the Office of the Secretary of the Northwest Bureau of the CC, about a third of the forests disappeared as result of the GLF projects. This, in turn, led to serious soil erosion and flooding, damaging hundreds of thousands of hectares of farmland and enlarging the Gobi Desert (Zhou 2012, 88).

In the Yellow River delta, the GLF irrigation projects led to severe water logging and alkalization. In December 1961, in his letter to Premier Zhou Enlai, the distressed Henan Provincial CCP Secretary, Liu Jianxun, noted: "In a few years the vast plain along the Yellow River will turn into a total wasteland" (Zhou 2012, 89). Hu Yaobang was head of the Youth League at the time. After spending twenty-five days touring around the Central China Plain, he was shocked by the destruction and environmental damage he saw in the countryside. Upon returning to Beijing he could not sleep and wrote a 
letter to the CC detailing what he had seen. Towards the end of his letter he wrote: "Unless one sees the situation with one's own eyes, it is impossible to believe how awful it is" (Zhou 2012, 90).

\section{CONCLUSION}

More than 100 documents that I collected were published in The Great Famine in China, 1958-1962 in English translation; they have enabled readers to grasp how and why the catastrophe unfolded and the enormity and sheer horror of what took place. These documents also help us to obtain a much fuller view of everyday life in Mao's China and to understand the complex and individual experiences of surviving famine and hunger under Communist rule. The documentary evidence allows scholars to deepen our understanding of issues already raised by Frank Dikötter, Yang Jisheng, and others, and to provide new perspectives on the history of the People's Republic of China.

\section{Works Cited}

"A Lesson to be Learned." November 1958. Hunan Provincial CCP Committee Archive, file 141-2-76. Print.

Bo, Yibo. Review of Several Major Policy Decisions and Incidents. Beijing: CCP Central CCP School Press, 1993. Print.

Chishui County CCP Committee. File 1-A14-15.

Conquest, Robert. Harvest of Sorrow: Soviet Collectivization and the Terror-Famine. New York: Oxford UP, 1986. Print.

Dikötter, Frank. Mao's Great Famine: The History of China's Most Devastating Catastrophe, 1958-1962. London: Bloomsbury, 2010. Print.

Ebrey, Patricia Buckley. Chinese Civilization: A Sourcebook. 2nd ed. New York: The Free Press, 2009. Print.

Fuyang Region CCP Committee File J3-2-278.

High Wang Ling. 中国农民反行为研究 1950-1980 [The Counter-Reaction of Chinese Peasants, 1950-1980]. Hong Kong: The Chinese UP, 2013. Print.

Jing, Jun. The Temple of Memories: History, Power, and Morality in a Chinese Village. Stanford: Stanford UP, 1996. Print.

Li, Rui. 南方出版社 [A Personal Experience of the Great Leap Forward]. Vol. 1. Hong Kong: Southern Press 1999. Print.

Lynne, Viola. Peasant Rebels under Stalin: Collectivization and the Culture of Peasant Resistance. New York: Oxford UP, 1996. Print.

Mao, Tse-tung/Zedong. “Get Organized.” Selected Works of Mao Tse-tung. Vol. 3. 2nd ed. Beijing: Foreign Language Press, 1967. 153-161. Print.

---. Jianguo yilai Mao Zedong wengao [Manuscripts of Mao Zedong since the Founding of the People's Republic of China]. Vol. 8. Beijing: Central Documentary Press, 2008. Print. 
Scott, James. Weapons of the Weak: Everyday Forms of Peasant Resistance. New Haven: Yale UP, 1989. Print.

Wang, Gengjin, et al., eds. Xiang cun san shi nian : Fengyang nong cun she hui jing ji fa zhan shi lu (1949-1983) [Thirty Years in the Countryside: A Faithful Record of the Development of the Social Economy in the Villages of Fengyang, 19491983]. Beijing: Nongcun duwu chubanshe, 1989. Print.

Yang, Jisheng. Tombstone: The Untold Story of Mao's Great Famine. London: Allan Lane, 2012. Print.

Yu, Xiguang, ed. 大跃进，苦日子，上书记 [A Collection of the Petitions Made during the Hard Times of the Great Leap Forward]. Hong Kong: Shidai chaoliu chubanshe, 2006. Print.

Zhou, Xun. Forgotten Voices of Mao's Great Famine, 1958-1962: An Oral History. New Heaven: Yale UP, 2014. Print.

---. The Great Famine in China, 1958-1962: A Documentary History. New Haven: Yale UP, 2012. Print. 
(c) 2016 East/West: Journal of Ukrainian Studies (ewjus.com) ISSN 2292-7956 Volume III, No. 2 (2016) 